\title{
USE OF THE PARTICIPATORY BUDGET \\ IN THE PROCESS OF CREATING \\ URBAN RECREATIONAL SPACE \\ (ON THE EXAMPLE OF SZCZECIN)
}

\author{
BEATA MEYER \\ University of Szczecin, Faculty of Economics and Management of Services, POLAND \\ e-mail: beata.meyer@wzieu.pl
}

RECEIVED

ACCEPTED

JEL

CLASSIFICATION

KEYWORDS

ABSTRACT
18 January 2018

2 September 2018

$\mathrm{H} 72, \mathrm{O} 18, \mathrm{R} 42$

urban space, recreation, participatory budget

Modern and competitive cities must offer their residents the highest possible quality of living, which is directly related to the character and quality of urban space, especially space of recreation. What hence becomes of key importance is the shaping of urban space which is attractive to the residents, as the future of urban areas depends mostly on the capacity of every city to maintain high attractiveness as a spot of widely understood consumption. One of the ways of improving life quality in cities is to create attractive and accessible recreational space which, while creating a friendly environment for leisure time activities, may impede the process of urban sprawl. In Poland next to activities carried out to that aim by local governments, in recent years there have been investments realized within Participatory Budgets which allow for the residents' participation in that process. Shaping recreational space in this case has a local dimension (both in the understanding of one's own district and the whole city - Szczecin in this case), and over the years a methodical approach of the residents may be seen in terms of choosing projects that are long-term (e.g. city bike) and create modern recreational space that fits the residents' needs.

\section{Introduction}

While functioning in a competitive environment municipal governments focus primarily on exogenic functions, the objective of which is to support the development of cities and build their competitive position. However, with the rapid development of urban areas, it has become apparent that an urban sprawl subsequently occurs, resulting from the city's residents moving to suburban and outskirt areas, which has many negative consequences. Considering 
that one of the main reasons for the move from urban to suburban areas is the quality of urban space, the creation of space which fulfills the residents' expectations seems to be a key issue. City residents have been increasingly interested in participating in many activities led mostly by local authorities, such as the activity of estate councils, as well as submitting projects and voting on the Participatory Budget. The aim of the paper is to try to identify and evaluate the significance of the Participatory Budget for the creation of urban recreational space, on the example of Szczecin.

\section{The process of shaping contemporary urban space}

The functioning of cities and urban (urbanized) areas encompasses so many various spheres of the economy and human existence that defining the concept of a city (urban/urbanized area) combines many branches of science (i.a. economy, geography, urban sciences or sociology) and remains a debatable issue (Nowak, Skotarczak, 2012, p. 101). A definition which synthesizes the general determinants of a city was formulated by $M$. Weber, who regarded a city as a fusion of three defining systems: the market, the administrative and political center and the urban community, taking into consideration such qualities as compactness, size and political autonomy of a city (Paszkowski, 2011, p. 14). Contemporary definitions treat the concept of a city very widely, oftentimes attempting to include all aspects of its functioning. According to Z. Paszkowski, a city is: a spatial and social creation of great complexity, developed within particular political, social and economic conditions, within a determined space. It reflects the actions of market forces in time and space and is a place of exchange of thought and civilization development, reflecting the goals, aspiration and culture of its residents (Paszkowski, 2011, p. 16). Treating cities as systems consisting of mutually related elements (Gorzelak, 2008, p. 454), with a positive correlation of the city's size and the diversification of its functions (Gorynia, Łaźniewska, 2012, p. 187), reflects their multifunctional character.

The size and diversification of functions in cities change not only within time and space, but what also varies is the rank and significance of any particular type of activity for the functioning of a city and its competitiveness (Meyer, 2015a, p. 213). An increasing importance is attributed to endogenic functions, which, encompassing types of activity the basic goal of which is to satisfy the internal needs of a city and creating desired life conditions for residents and business owners, had not been perceived as a factor of importance in building a city's competitive position. That role has for a long time been attributed first and foremost to exogenic functions, which are directed at individuals from outside the city who build the city's relations with other areas and subjects. However, in recent years a tendency has become apparent to substitute traditional "hard" development factors (i.a. infrastructure, land rent, cluster benefits) for "soft" ones such as living conditions, aesthetic surroundings or attractivity for tourists (Bontje, Musterd, 2009, p. 849). The ongoing processes of uncontrollable urban sprawl (Zhang, 2004, pp. 56-57; Sudhira, Ramachandra, 2007, p. 1), their negative consequences on all platforms (environmental, social and economical) as well as the cost borne mostly by the city both in a financial and social sense (Karakayaci, 2016, p. 817; Correia, de Abreu e Silva, 2015; Couch, Petschel-Held, Leontidou, 2008, p. 294) have drawn attention also to the reasons behind urban sprawl. Among those, factors connected with the decrease of living quality in cities clearly stand out. They include lack of the feeling of safety and the mediocrity of school facilities as well as the environmental issues concerning the surroundings the residents live in: noise, smog, lack of green areas, lack of attractive leisure space (Karakayaci, 2016, p. 817) and lack of competence among urban planning services in terms of controlling spatial development. This clearly indicates the significance of environment quality for city residents, who, in search of better living conditions, decide to leave the central areas of a city and move to the suburbs. 
What hence becomes of key importance is the shaping of urban space which is attractive to the residents, as the future of urban areas depends mostly on the capacity of every city to maintain high attractiveness as a spot of widely understood consumption. Among the determinants which favor the creation of cities as consumption centers a group of factors can be distinguished, encompassing amenities related to the aesthetics of surroundings and comfort of living and resulting from physical and geographical conditions (i.a. climate including the weather, environment cleanliness, location, attractiveness of the environment). The most important and obvious factor remains the plurality and diversity of goods and services offered, both of global and local character. The remaining determinants focus on the accessibility and quality of public goods (one of the consequences being the sense of security) and the accessibility of urban areas which determines the access to consumption goods (Meyer, 2016, p. 434).

Increased mindfulness in the process of shaping urban space fits in with the contemporary trend of creating $X X Q$ cities (or cities with $X X Q$ factor), which have for a long time been considered the example of a "perfect city" by urbanists. XXQ (XXQuality) cities are cities that offer the best possible quality of life (XXQ size). Within the five factors determining the quality of living the second one are ecological resources (Mierzejewska, 2011, p. 89), signifying environmental bases which condition the residents' quality of life (clean environment, low noise level) and determine the urban greenery areas, water resources and open space resources thereby guaranteeing a sufficient level of biodiversity (Nijkamp, 2008, p. 12). A perfect city, in turn, is currently understood as a "challenge to create a perfect living environment for humans, which should satisfy both the needs of the individual, person, resident and the needs of a community which constitutes an urban, local and regional society. (...) Contemporary idealism encompasses not only the good of an urban society (in the understanding of renaissance theorists and utopians), but also the need for balancing civilisation development with the protection of the natural environment and climate, especially in the context of global urbanization issues" (Paszkowski, 2011, p. 19). Modern and competitive cities must therefore offer their residents the highest possible quality of living, which is directly related to the character and quality of urban space.

\section{Recreation as one of the factors shaping urban space}

Within many functions performed by the city which influence the shaping of its space, it is possible to distinguish recreation as one of the key functions related to the residents' mood and well-being, and, as a consequence, their quality of life. According to T. Wolańska, recreation "comprises various activities that are undertaken in one's free time, voluntarily, for pleasure, for the development of one's personality, or to restore and increase one's psychological and physical capacity" (Meyer, 2015b, p. 356). A similar definition has been proposed by A. Kowalczyk, in which recreation includes "any activity undertaken voluntarily with a view to restoring one's physical and psychological capacity, specifically including participation in culture, games, and sports, which takes place in time that is free from school, work, or household activities" (Kowalczyk, 2000, p. 287). The definition by S. Tanaś is concise, but contains the same main attributes, stating that recreation is "any form of regeneration of human capacities by spending one's free time in an active or passive manner" (Tanaś, 2008, p. 10). A comprehensive definition of recreation, comprising its key aspects, has been formulated by A. Dabrowski: "all socially acceptable forms of human activity taking place in one's free time; undertaken voluntarily, gratuitously, and for pleasure; which serve to restore and enhance one's capacities, enable playful, active, and diverse self-realization; and are performed individually or in groups, or occur as a global process" (Dąbrowski, 2006, p. 37). 
Recreational space has not yet been clearly or satisfactorily defined, nor systematized in detail (as opposed to tourist space, which has been defined, classified, and categorized by many authors, including Liszewski, 1995; Liszewski, 2013; Włodarczyk, 2014; Kowalczyk, 2014; Więckowski, 2014). The most commonly cited definition is the one by M. Drzewiecki, defining recreational space as "a fragment of geographical space with characteristics enabling and conducive to various forms of leisure, where recreational processes of a socially and spatially significant extent occur" (Drzewiecki, 1992, p. 37). According to S. Toczek-Werner, in a (recreational) space used for recreational activities, one can distinguish recreational activity centers (fulfilling the expectations and needs of individuals who prefer specific forms of activity - e.g. fitness centers, swimming pools, dance studios) and areas than enable recreation without restricting its form (e.g. parks, squares, sports fields, playgrounds) (Toczek-Werner, 2007, p. 18).

For the purpose of the present paper, recreational space is assumed to be any space where recreational activities are undertaken. The nature of a given location allows for distinguishing between open (outdoor) and closed (indoor) spaces, and for identifying spaces associated with a specific type of recreational activity (e.g. swimming, dancing, walking). Additionally, each space type may be considered formal (where activities are organized and/or provided for a charge) or informal (where activities are undertaken individually and free of charge). Recreational space is most often perceived in the context of activities undertaken by residents of an area in their spare time.

Shaping recreational space in cities remains to a significant degree in the power of local authorities, which are legally compelled to satisfy collective needs of the community by creating conditions for rational and harmonic growth and conditions for full participation of the residents in the life of the community. Dedicated tasks of the local governments are directly related to shaping urban space, as they encompass issues of social and technical infrastructure, civil order and safety as well as spatial and ecological order. The necessity for maintaining spatial and ecological order is particularly determined by the local government's responsibility for the spatial organization of the city, which should take into consideration the residents' needs in terms of quality of living, including leisure time recreational activity.

Over the last 10 years the idea of a participatory budget has developed in Poland. The mechanism of such a budget was created in 1990 in Porto Alegre, Brasil; in Poland it was first implemented by the city of Sopot in 2011 (Dolewka, 2015, p. 63). The participatory budget is most often defined as a "process, during which the residents of a given territorial unit directly decide or participate in making decisions about the allocation of the entirety or a part of available public funding" (Kocot, 2014, p. 84). The participatory budget is similarly defined by international institutions (World Bank's Empowerment..., 2018) or foreign researchers active in this area (Wampler, 2007, p. 21). The essence of a participatory budget has also been described by, a.o., M. Dworakowska (2014, p. 63), G. Kocot (2014, p. 84), E. Wojciechowski (2016, p. 380), M. Piotrowski et al. (2014, p. 69), H. Silver, A. Scott, Y. Kazepov (2010, p. 472), Z. Dolewka (2015, p. 63), K. Leśniewska-Napierała (2017, p. 10), and the particulars of its construction can be found in the works of W. Kębłowski (2013; 2014). The concept of residents participating in the decision-making process regarding their closest surroundings prompts them to become active participants in the process of shaping space, including, to a significant degree, recreational space. This way recreational space remains in the center of the residents' scope of interest as space where they can realize their activities not related to work duties and the quality of which significantly impacts their comfort of living. 


\section{The participatory budget and the recreational space in Szczecin}

The recreational space in Szczecin is determined by the extensity and specificity of the city's natural environment. Szczecin has a large surface area (approx. $301 \mathrm{~km}^{2}$ ), where green areas account for $17.54 \%$ of the total area, which, combined with bodies of water (23.68\%) and agricultural land, gives $60.81 \%$ of the total area of the city (Raport..., 2017). This large share of green areas and bodies of water has a strong impact on the character of the city and creates favorable conditions for recreation. Enjoyment of the natural environment is facilitated by the constantly developing infrastructure (marinas, beaches, forest clearings, educational trails, hiking trails, cycling roads). Furthermore, the city has extensive facilities for undertaking a variety of recreational activities. These mainly include buildings and infrastructure for recreational sports, such as stadiums (12), sports fields (231), indoor swimming pools (8), marinas (12), tennis courts (7), or outdoor gyms (14). Various businesses and institutions use the city's technical facilities to enable the pursuit of various interests - e.g. sports clubs (273), gyms and fitness centers, dance schools, community centers etc. Infrastructure for culture and entertainment includes a concert hall (which hosted 436 events in 2016), cinemas (5), museums (7), and theaters (5).

The development of recreational space which would enable the residents to spend their leisure time appealingly seems to be one of the urban authorities' priorities. The long-standing Szczecin Development Programme for the years 2017-2023 has a total budget of 3705068666 PLN (Wieloletni Program Rozwoju Szczecina 2017-2021 z perspektywą do 2023 roku), intended for the realization of four main goals. Almost 2/3 of that amount has been directed to the realization of the "IV Szczecin - an attractive metropolitan city" goal, which involves tasks related to improving transport accessibility and the communication outline of the city as well as supporting growth and harmonization of Szczecin's metropolitan functions and the realization of projects which increase the city's prestige. It can be assumed (after analyzing projects planned for realization) that to a large degree those are projects which impact the shape of recreational space. Almost $16 \%$ of the budget $(752,880,805$ PLN) is directly dedicated to the realization of objectives related to the goal "I Szczecin - city of high living quality". Those are practically exclusively projects which directly or indirectly shape recreational space or increase its quality, encompassing tasks from the area of protection and usage of natural resources, revitalization and development of urban space as well as supporting the development of effective social services. Among the projects planned within the remaining goals, II Szczecin - city of modern, competitive and innovative economy and III Szczecin - city of a high intellectual capital potential solutions can also be found that influence the form and quality of recreational space. Especially within the scope of goal II, where one of the tasks has the aim of dynamizing tourism development while using natural resources and the historical and cultural heritage, which will directly influence recreational space in the city.

Simultaneously with activities undertaken by local governments as part of their legal duties, since 2013 there have also been investments undertaken which had been chosen by the residents by way of discussion and voting on the proposed projects. The process of creating and realizing the Participatory Budget evolved for three years, to finally assume a continual form in 2016. The procedure begins with the residents submitting a proposal of tasks on a special application form, which is sorted to the right category depending on the area of concern. There is a distinction between city-wide projects and four groups of district projects - North district, Prawobrzeże district, City Center district and West district. By way of voting by authorised individuals projects for realization are elected.

In 2018 over 26,000 residents participated in the Participatory Budget vote, casting 75,047 votes (http://bip. um.szczecin.pl, 2018). 13 projects were chosen from over 100 submitted to the 2018 Szczecin Participatory Budget. Those were, i.a., the revitalization of Żeromski Park, a welcome mural for out of town guests at the railway station 
exit on Owocowa St., creation of "The Best Playground in the City" in Prawobrzeże district or the Szwaja Literary Garden. The resource pool for this edition of the SPB is 8 million PLN. Most of the projects chosen have a sports profile, and Arkonia Szczecin won in three categories - including the main category, the city-wide project. In Lasek Arkoński park there will be a new pitch as well as the first air dome in the voivodeship with a removable roof.

In 2017 over 34,000 residents participated in the Participatory Budget vote, casting 94,964 votes (http://bip. um.szczecin.pl, 2018). The budget amounted to 7 million PLN and the residents could choose from 122 submitted projects. Table 1 presents the list of winning projects of the Szczecin Participatory Budget for 2017 and 2018.

Table 1. List of winning projects of the Szczecin Participatory Budget in 2017 and 2018

\begin{tabular}{|c|c|c|c|c|}
\hline \multirow{2}{*}{ Area } & \multicolumn{2}{|l|}{ SPB 2017} & \multicolumn{2}{|l|}{ SPB 2018} \\
\hline & name of the project & number of votes & name of the project & number of votes \\
\hline \multicolumn{5}{|c|}{ CITY-WIDE GOALS } \\
\hline SZCZECIN & Bukovasport & 5,160 & $\begin{array}{l}\text { Modernization of football fields at the k.s. Arkonia } \\
\text { Szczecin stadium on Arkońska St. (stadium) as } \\
\text { well as the social building }\end{array}$ & 4,260 \\
\hline \multicolumn{5}{|c|}{ BIG DISTRICT GOALS } \\
\hline North & $\begin{array}{l}\text { Brodowski Żelechowa Park - sensory } \\
\text { playground, sports and recreation zone }\end{array}$ & 1,517 & $\begin{array}{l}\text { Construction of a modern indoor synthetic pitch on } \\
\text { Nehringa St. } 69\end{array}$ & 1,107 \\
\hline $\begin{array}{l}\text { Prawobrzeże } \\
\text { District }\end{array}$ & $\begin{array}{l}\text { Foundation for animals Dzika Ostoja } \\
\text { - rehabilitation center for wild animals } \\
\text { including a retreat and educational } \\
\text { purposes }\end{array}$ & 3,742 & Freedom Szczecin - best playground in the city & 2,511 \\
\hline City center & Level pavements for Szczecin & 959 & $\begin{array}{l}\text { Revitalization of alleyways and surrounding } \\
\text { modernizations in Żeromski Park }\end{array}$ & 704 \\
\hline West & $\begin{array}{l}\text { Multifunctional pitch at Arkonka by Arkonia } \\
\text { Szczecin Stadium }\end{array}$ & 2,968 & $\begin{array}{l}\text { Purchase and installation of an air dome with } \\
\text { a lighting and heating system over the football } \\
\text { pitch on Arkońska St. (stadium) measuring } \\
100 \mathrm{~m} \times 50 \mathrm{~m}\end{array}$ & 3,635 \\
\hline \multicolumn{5}{|c|}{ SMALL DISTRICT GOALS } \\
\hline \multirow[t]{2}{*}{ North } & 1. City bike station on Duńska St. & 1,286 & $\begin{array}{l}\text { 1. Construction and modernization of the parking } \\
\text { lot and pavements of the leisure and sports } \\
\text { facility on Nehringa St. }\end{array}$ & 1,096 \\
\hline & $\begin{array}{l}\text { 2. Flowers in the city - Przyjaciół Żołnierza } \\
\text { St. }\end{array}$ & 1,145 & 2. Construction of lighting on Pszczelna St. & 717 \\
\hline \multirow[t]{2}{*}{$\begin{array}{l}\text { Prawobrzeże } \\
\text { District }\end{array}$} & $\begin{array}{l}\text { 1. Revitalization of a fragment of ks. Albert } \\
\text { Wilimsky park in Podjuchy }\end{array}$ & 3,397 & 1. Szwaja Literary Garden & 2,311 \\
\hline & 2. Rose gardens in Kijewo district & 2,380 & 2. Rose gardens II & 808 \\
\hline \multirow[t]{2}{*}{ City center } & 1. City bike station by TME & 849 & $\begin{array}{l}\text { 1. Szczecin - giant inscription as a tourist } \\
\text { attraction and interesting souvenir photo } \\
\text { opportunity }\end{array}$ & 946 \\
\hline & 2. Intelligent solar furniture (votes) & 799 & $\begin{array}{l}\text { 2. Welcome to Szczecin - mural on a wall on } \\
\text { Owocowa St. opposite the new railway station } \\
\text { entrance }\end{array}$ & 662 \\
\hline \multirow[t]{2}{*}{ West } & $\begin{array}{l}\text { 1. Bike and pedestrian track by Głębokie } \\
\text { Lake on the side of Ppłk. H. Kupczyka } \\
\text { St. allowing for a collision-free and safe } \\
\text { passage around the lake }\end{array}$ & 3,222 & $\begin{array}{l}\text { 1. Construction of a sports ability zone by } \\
\text { Arkońska (stadium) St. }\end{array}$ & 4,489 \\
\hline & $\begin{array}{l}\text { 2. Street Workout gym at the Arkonia } \\
\text { Szczecin stadium }\end{array}$ & 2,851 & $\begin{array}{l}\text { 2. Safe parking - safe children. Construction } \\
\text { of a parking lot by Elementary School no. } 53\end{array}$ & 1,759 \\
\hline
\end{tabular}

Source: own elaboration based on http://bip.um.szczecin.pl. 
In former years the residents had chosen the following investments:

3. In 2016 the Participatory Budget allocated $6 \mathrm{mln}$ PLN, almost 35,000 people voted, 64,558 votes were cast, and the following projects won:

- Szczecin City Bike - stage two (West District),

- Warszewo - Podbórz Park (North District),

- reconstruction of the intersection of Przelotowa, Łubinowa, Nałkowskiej and Handlowa Streets aimed at improving traffic flow and safety,

- Flower Avenue covered in flowers (City Center District).

4. In 2016 the Participary Budget allocated $5 \mathrm{mln}$ PLN, over 48,000 people voted, 84,822 votes were cast, and the following projects won:

- realization of an investment consisting in the repair and modernization of a shelter for stray animals in Szczecin - city-wide project,

- bike revolution - 20 bike tracks in the city - city-wide project,

- construction of a dog park in the City Center of Szczecin - city-wide project,

- repair of the pavement and bus stops on Asnyka St. plus additional shelters and rearranging the green area to make it functional and aesthetically pleasing City Center District,

- modernization of the underpass under Wyzwolenia Av. - City Center District,

- Arkonka and Goplana - refreshment and marking of the tourist-recreational trail along with placement of benches - West District,

- construction of a multifunctional pitch, pavements and infrastructure area management on Krakowska, Zbójnicka and Lwowska Streets - West District,

- adaptation and renovation of a sports pitch including the construction of sanitary and social infrastructure - Prawobrzeże District,

- hardening of the surface of Głęboka St. - North District.

5. In 2014 the Participatory Budget allocated $5 \mathrm{mln}$ PLN, 69178 votes were cast, and the following projects won:

- Szczecin City Bike,

- Modernization of Brodowski Lake and surrounding areas.

Analysis of the projects submitted and chosen by the residents within the participation in the city's land planning indicates an increasing care about the quality of their immediate surroundings and access to attractive areas dedicated to varied forms of recreation. Among the winning projects in the previous editions of the Szczecin Participatory Budget there are many projects aimed at solving the residents' transport-related problems (parking lots, pedestrian crossings, pavements, road surface), but the recent editions were dominated by investments related to recreation areas as well as recreational, representative, sports or culturally relevant objects. This may indicate that the residents of Szczecin (leaving aside the attendance) see the need for expanding, modernizing, increasing the attractiveness and accessibility of recreational areas, which they make use of more and more frequently, and pay increasingly more attention to the quality of their immediate surroundings. Such choices contribute to shaping recreational space first and foremost on a local scale, meaning their own district (or even a part thereof), but also (by choosing city-wide projects) the entire urban area. The latter type of investment allows for the shaping and 
development of recreational space in a concise manner suited to the needs of the entire community and accessible to most of its members.

\section{Conclusions}

Problems related to the functioning of urban areas, especially with the move of residents to the suburbs of cities (and the negative consequences thereof) arise to a high degree from the decreasing comfort of life in the cities and the search for more optimal living conditions on the part of the residents. One of the ways of improving life quality in cities is to create attractive and accessible recreational space which, while creating a friendly environment for leisure time activities, may impede the process of urban sprawl. Next to activities carried out to that aim by local governments, in recent years there have been investments realized within Participatory Budgets which allow for the residents' participation in that process. On the example of the projects chosen by the residents of Szczecin as part of the Participatory Budget it can be seen that the residents pay increasingly more attention to the aesthetics of their immediate surroundings and the possibility of obtaining a friendly and attractive space for their leisure time activities. Shaping recreational space in this case has a local dimension (both in the understanding of one's own district and the whole city), but over the years a methodical approach of the residents may be seen in terms of choosing projects that are to create a particular space, which is not possible within a single year (e.g. city bike, or the surroundings of Brodowski Park). This clearly contributes to creating modern recreational space that fits the residents' needs.

\section{References}

Bontje, M., Musterd, S. (2009). Creative industries, creative class and competitiveness: Expert opinions critically appraised. Geoforum, 40 (5), 843-852.

Correia, M., de Abreu e Silva, J. (2015). The Costs of Urban Sprawl on Portuguese Municipalities in 2011. Conference Paper. 55th Congress of the European Regional Science Association: "World Renaissance: Changing roles for people and places", Lisbon. Retrieved from: http://hdl.handle.net/10419/124757.

Couch, C., Petschel-Held, G., Leontidou, L. (eds.) (2008). Urban Sprawl in Europe: Landscape, Land-Use Change and Policy. USA: Wiley-Blackwell. DOI:10.1002/9780470692066.

Dąbrowski, A. (ed.). (2006). Zarys teorii rekreacji ruchowej. Warszawa: Wydawnictwo ALMAMER WSE. DOI: 10.17719/jisr.20164520658.

Dolewka, Z. (2015), Budżet partycypacyjny w teorii i w praktyce. Prace Naukowe Uniwersytetu Ekonomicznego we Wrocławiu, 408, 62-74. DOI:10.15611/pn.2015.408.04.

Drzewiecki, M. (1992). Wiejska przestrzeń rekreacyjna. Warszawa: Instytut Turystyki.

Dworakowska, M. (2014). Rola i znaczenie budżetu partycypacyjnego w rozwoju społeczeństwa obywatelskiego. In: J. Osiński, J. Popławska (eds.), Oblicza społeczeństwa obywatelskiego - państwo, gospodarka, świat. Warszawa: Szkoła Głowna Handlowa.

Gorynia, M., Łaźniewska, E. (ed.) (2010). Kompendium wiedzy o konkurencyjności. Warszawa: Wydawnictwo Naukowe PWN.

Gorzelak, M. (2008). Miasto jako przedmiot badań w ekonomii. In: B. Jałowiecki (ed.), Miasto jako przedmiot badań naukowych w początkach XXI wieku. Warszawa: Scholar.

http://bip.um.szczecin.pl/chapter_11000.asp.

Karakayaci, Z. (2016). The concept of urban sprawl and its causes. Journal of International Social Research, 9 (45), 815-818.

Kębłowski, W. (2013). Budżet partycypacyjny. Krótka instrukcja obsługi. Warszawa: Instytut Obywatelski. Retrieved from: www. instytutobywatelski.pl/14426/publikacje/raporty/raport-budzet-partycypacyjny-krotka-instrukcja-obslugi.

Kębłowski, W. (2014). Budżet partycypacyjny. Ewaluacja. Warszawa: Instytut Obywatelski. Retrieved from: www.instytutobywatelski. pl/21598/publikacje/raporty/raport-budzet-partycypacyjny-ewaluacja. 
Kocot, G. (2014). Budżet partycypacyjny w Polsce. In: J. Osiński, J. Popławska (eds.), Oblicza społeczeństwa obywatelskiego państwo, gospodarka, świat. Warszawa: Szkoła Główna Handlowa.

Kowalczyk, A. (2000). Geografia turyzmu. Warszawa: Wydawnictwo Naukowe PWN.

Kowalczyk, A. (2014). Fenomenologia przestrzeni turystycznej. Turyzm, 24 (1), 9-15.

Leśniewska-Napierała, K. (2017). Budżet partycypacyjny jako narzędzie finansowania inwestycji w Łodzi. Studia Miejskie, 25, 107-119 DOI: $10.25167 / \mathrm{sm} 2017.025 .06$.

Liszewski, S. (1995). Przestrzeń turystyczna. Turyzm, 5 (2), 87-103.

Liszewski, S. (2013). Treści, formy, przestrzenie i klasyfikacje turystyki (artykuł dyskusyjny). In R. Wiluś, J. Wojciechowska (eds.), Nowe - stare formy turystyki w przestrzeni (pp. 9-20). Łódź: Wydawnictwo Uniwersytetu Łódzkiego.

Meyer, B. (2015a). Środowiskowe aspekty kształtowania przestrzeni turystycznej w miastach, na przykładzie Szczecina. In: E. BilskaWodecka, I. Sołjan (eds.), Geografia na przestrzeni wieków. Tradycja i współczesność (pp. 309-325). Kraków: Instytut Geografii i Gospodarki Przestrzennej Uniwersytetu Jagiellońskiego w Krakowie.

Meyer, B. (2016). Tourism Activity in Urban Space on the Example of Szczecin. In: F. Dias (ed.), A pathway for the new generation of tourism researc - proceedings of the EATSA Conference 2016 (pp. 431-441). Lizbon: Grácio.

Meyer, B. (ed.) (2015b). Obsługa uczestników turystyki i rekreacji. Wybrane aspekty. Warszawa: Difin.

Mierzejewska, L. (2011). W poszukiwaniu nowych modeli rozwoju miast. Studia Miejskie, 4, 81-94.

Nijkamp, P. (2008). XXQ factors for sustainable development: A systems economic view. Romanian Journal of Regional Science, 2 (1), $1-34$.

Nowak, M.J., Skotarczak, T. (ed.) (2012). Zarządzanie przestrzenią miasta. Warszawa: CeDeWu.

Paszkowski, Z. (2011). Miasto idealne. W perspektywie europejskiej i jego związki ze współczesną urbanistyką współczesną. Kraków: Universitas.

Piotrowski, M., Dzieżyc, H., Adamczyk-Mucha, K., Walter, E., Ziemiańska, M. (2014). Analiza wyników głosowania nad budżetem obywatelskim Wrocławia w 2013 roku. Architektura Krajobrazu, 3, 68-77.

Raport o stanie miasta Szczecin 2016 (2017). Retrieved from: http://bip.um.szczecin.pl/chapter_11808.asp?soid=E1F8717034EF4BC4 A54CDD4C73258EB4.

Silver, H., Scott, A., Kazepov, Y. (2010). Participation in Urban Contention and Deliberation. International Journal of Urban and Regional Research, 34 (3), 453-477.

Sudhira, H.S., Ramachandra, T.V. (2007). Characterising Urban Sprawl from Remote Sensing Data and Using Landscape Metrics. Proceedings of 10th International Conference on Computers in Urban Planning and Urban Management, PR Brazil: Iguassu Falls.

Tanaś, S. (2008). Miejsce cmentarzy w turystyce kulturowej - wokół problemu badawczego. Turystyka Kulturowa, 2, 4-16.

Toczek-Werner, S. (2007). Podstawy rekreacji i turystyki. Wrocław: Wydawnictwo Akademii Wychowania Fizycznego.

Wampler, B. (2007). A Guide to participatory budgeting. In: A. Shah (ed.), Participatory Budgeting. Worldbank.

Wieloletni Program Rozwoju Szczecina 2017-2021 z perspektywą do 2023 roku (2018). Retrieved from: http://bip.um.szczecin.pl/ chapter_50827.asp.

Więckowski, M. (2014). Przestrzeń turystyczna - próba nowego spojrzenia. Turyzm, 24 (1), 17-34.

Włodarczyk, B. (2014). Przestrzeń w turystyce, turystyka w przestrzeni - o potrzebie definicji, delimitacji i klasyfikacji. Turyzm 24 (1), $25-35$.

Wojciechowski, E. (2016). Problem budżetu obywatelskiego. In: R.P. Krawczyk, A. Borowicz (eds.), Aktualne problemy samorządu terytorialnego po 25 latach jego istnienia. Łódź: Wydawnictwo Uniwersytetu Łódzkiego.

World Banks Empowerment. Case Studies: Participatory Budgeting in Brazil (2018). Retrieved from: http://siteresources.worldbank.org/ INTEMPOWERMENT/Resources/14657_Partic-Budg-Brazil-web.pdf.

Zhang, B. (2004). Study on Urban Growth Management in China. China: Xinhua Press.

Cite this article aS: Meyer, B. (2018). Use of the participatory budget in the process of creating urban recreational space (on the example of Szczecin). European Journal of Service Management, 3 (27/2), 289-297. DOI: 10.18276/ejsm.2018.27/2-35. 